\title{
Prediction of Stem Cell Mobilization Failure in Patients with Hodgkin and Non-Hodgkin Lymphoma
}

\author{
Hodgkin ve Non-Hodgkin Lenfomalı Hastalarda Kök Hücre Mobilizasyon Başarısızlığının \\ Öngörüsü
}

(D) Haluk Demiroğlu, (D) Rafiye Çiftçiler, (D) Yahya Büyükaşık, (D) Hakan Göker

Hacettepe University Faculty of Medicine, Departments of Hematology, Ankara, Turkey

\section{Abstract}

Objective: Autologous stem cell transplantation (ASCT) is a significant and potentially curative treatment modality for patients with relapsed/refractory lymphoma. Insufficient mobilization and harvest of peripheral stem cells can be a major obstacle for performing ASCT. The aim of this study was to evaluate the factors that might influence mobilization failure in patients with lymphoma.

Materials and Methods: Eighty-seven patients diagnosed with non-Hodgkin and Hodgkin lymphoma who underwent stem cell mobilization afterwards at the Hacettepe University Medical School Bone Marrow Transplantation Center, Turkey, between the years of 2000 and 2018 were evaluated.

Results: A total of 87 patients were included in this study. In 66 of 87 patients (75.9\%), the first mobilization trial was successful. Adequate $(\geq 2 \times 106 / \mathrm{kg}) \mathrm{CD} 34+$ cells were collected in the first apheresis for 66 patients $(9.5 \pm 8.1)$. For 21 of 87 (24.1\%), the first mobilization trial was unsuccessful. Therefore, a second mobilization trial was performed for these patients with plerixafor $(5.5 \pm 3.3)$. The number of CD34+ cells was significantly higher in patients who were successful in the first mobilization ( $p=0.002)$.

Conclusion: The success rate of the first mobilization trial was found to be higher in patients with high platelet counts before mobilization and patients who received chemotherapy-based mobilization protocols. In the patients who had mobilization failure in the first trial, plerixafor was used in a later mobilization, and those patients had an adequate amount of stem cells for ASCT. Parameters predicting mobilization failure would allow for preemptive, more cost-effective use of such agents during the first mobilization attempt; however, risk factors for mobilization failure are still not clear.

Keywords: Hodgkin lymphoma, Non-Hodgkin lymphoma, Stem cell mobilization, Mobilization failure

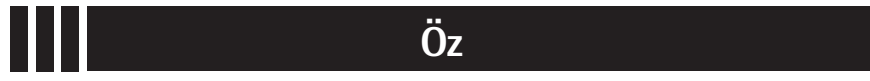

Amaç: Otolog kök hücre transplantasyonu (OKHT), relaps/refrakter lenfoma hastaları için önemli ve potansiyel olarak küratif bir tedavi yöntemidir. Yetersiz mobilizasyon ve periferik kök hücrelerin toplanması OKHT'nin gerçekleştirilmesi için büyük bir engel olabilir. Bu çalışmanın amacı lenfoma hastalarında mobilizasyon başarısızlığını etkileyebilecek faktörleri değerlendirmektir.

Gereç ve Yöntemler: Hacettepe Üniversitesi Tıp Fakültesi Kemik İliği Nakil Merkezi'nde 2000-2018 yılları arasında Hodgkin ve non-Hodgkin lenfoma tanısı alan ve sonrasında kök hücre mobilizasyonu yapılan 87 hasta değerlendirildi.

Bulgular: Bu çalışmaya toplam 87 hasta dahil edildi. Seksen yedi hastanın 66'sında $(\% 75,9)$ ilk mobilizasyon denemesi başarılı oldu. 66 hastada $(9,5 \pm 8,1)$ ilk aferezde yeterli $(\geq 2 \times 106 / \mathrm{kg})$ CD34+ hücre toplandı. Seksen yedi kişiden 21'i $(\% 24,1)$ için ilk mobilizasyon denemesi başarısız oldu. Bu nedenle bu hastalara pleriksafor ile $(5,5 \pm 3,3)$ ikinci bir mobilizasyon denemesi yapıldı. İlk mobilizasyonda başarılı olan hastalarda CD34+ hücre sayısı anlamlı olarak yüksekti $(p=0,002)$.

Sonuç: Mobilizasyon öncesi trombosit sayısı yüksek olan hastalarda ve kemoterapi bazlı mobilizasyon protokolleri alan hastalarda ilk mobilizasyon denemesinin başarı oranı daha yüksek bulundu. İlk denemede mobilizasyon başarısızlığı olan hastalarda daha sonraki mobilizasyonda pleriksafor kullanılmış ve bu hastalarda OKHT için yeterli miktarda kök hücre mevcuttu. Mobilizasyon başarısızlığını öngören parametreler, ilk mobilizasyon girişimi sırasında bu tür ajanların önleyici, daha uygun maliyetli kullanımına izin verecektir; ancak, mobilizasyon başarısızlığı için risk faktörleri hala net değildir.

Anahtar Sözcükler: Hodgkin lymphoma, Non-Hodgkin lymphoma, Kök hücre mobilizasyonu, Mobilizasyon başarısızlığı

๑Copyright 2021 by Turkish Society of Hematology

Turkish Journal of Hematology, Published by Galenos Publishing House 


\section{Introduction}

Autologous stem cell transplantation (ASCT) is a significant and potentially curative treatment modality for patients with relapsed/refractory lymphoma. However, 5\%-40\% of lymphoma patients fail to mobilize sufficient peripheral blood stem cells and thus cannot undergo ASCT, which is known to improve survival [1]. Hematopoietic stem cells generally circulate in very small numbers in the peripheral blood and have to be mobilized into the circulation prior to being collected by apheresis. Peripheral blood stem cell (PBSC) mobilization is accomplished by administration of granulocyte colony-stimulating factor (G-CSF) alone or in combination with chemotherapy [2]. Peripheral blood has been shown to be superior to bone marrow as a source of hematopoietic stem cells for ASCT [3]. Insufficient mobilization and harvest of peripheral stem cells can be a major obstacle for performing ASCT. Currently, a minimum of $2 \times 10^{6} \mathrm{CD} 34+$ cells $/ \mathrm{kg}$ hematopoietic stem cells is considered appropriate in most centers to proceed to ASCT. This threshold is necessary for a rapid and sustained blood count recovery and for reduced hospitalization, blood product usage, and infections [4]. However, the optimal hematopoietic stem cell dose is about $5 \times 10^{6} / \mathrm{kg}$ [5]. Bone marrow infiltration, advanced age, number of prior cytotoxic therapies, and myelodysplastic changes are the best defined factors associated with increased risk of mobilization failure $[6,7]$.

We have collected and analyzed data from a series of nonHodgkin and Hodgkin lymphoma patients who received ASCT in order to determine the frequency of harvest failure and to identify factors influencing PBSC mobilization outcomes. The aim of this study was to evaluate the factors that might influence mobilization failure in patients with lymphoma.

\section{Materials and Methods}

\section{Study Design and Data Collection}

This study was performed in a retrospective manner. Demographic data of the patients, treatment regimens, and stem cell mobilization data updates were obtained from the hospital database. As a result of the application standards of the hospitals of the Hacettepe University Medical School Bone Marrow Transplantation Center, Turkey, it has been recognized from the patient records that all of the studied patients had given informed consent at the time of hospitalization and before the administration of chemotherapy and other relevant diagnostic/ therapeutic standards of care. Patients gave informed consent for procedures in accordance with the Declaration of Helsinki.

\section{Patients and Disease Characteristics}

Eighty-seven patients diagnosed with non-Hodgkin and Hodgkin lymphoma who underwent stem cell mobilization afterwards at the Hacettepe University Medical School Bone Marrow
Transplantation Center between the years of 2000 and 2018 were evaluated. The key inclusion criteria were patients $\geq 18$ years of age diagnosed with non-Hodgkin or Hodgkin lymphoma who required systemic chemotherapy and underwent ASCT with Eastern Cooperative Oncology Group (ECOG) performance status (PS) of <2 [8] with an indication for ASCT.

Median age, gender, ECOG PS, lymphoma subtypes, stage at diagnosis, bone marrow infiltration at diagnosis, induction chemotherapy, salvage chemotherapy, chemotherapy cycles received before mobilization, radiotherapy before mobilization, platelet count before mobilization, mobilization protocols, and disease status before ASCT were compared for patients who had successful stem cell mobilization and those with stem cell mobilization failure. Additionally, disease status after ASCT, relapse rate, and mortality results were evaluated between these groups. The target CD34+ cell dose for collection was $>2 \times 10^{6} / \mathrm{kg}$ for each planned autograft. All patients received G-CSF at a dose of $10 \mu \mathrm{g} /$ $\mathrm{kg}$ from day +5 until the peripheral stem cell harvest. CD34+ cells were measured in peripheral blood and apheresis products by flow cytometry. We had a CD34+ cut-off level of $20 \mu \mathrm{L}$ for starting apheresis. We harvested the cells on the $5^{\text {th }}$ and/or $6^{\text {th }}$ day after beginning G-CSF administration. Peripheral blood CD34\% and $\mathrm{CD} 34 / \mu \mathrm{L}$ values at the first day on which leukocytes reached the value of $1 \times 10^{9} / \mathrm{L}$ and were maintained above that threshold over at least 2 days were correlated with overall CD34+ collection. A harvest of less than $2 \times 10^{6} \mathrm{CD} 34+/ \mathrm{kg}$ was considered as mobilization failure. Twenty-one patients received plerixafor as an additional mobilizing agent for the second apheresis. Subcutaneous plerixafor $(0.24 \mathrm{mg} / \mathrm{kg})$ was administered to the patients on the evenings of the $4^{\text {th }}$ and $5^{\text {th }}$ days of the mobilization protocol.

\section{Statistical Analysis}

Statistical analyses were performed using SPSS 25 (IBM Corp., Armonk, NY, USA). Variables were investigated using visual (histograms, probability plots) and analytical (Kolmogorov-Smirnov/Shapiro-Wilk test) methods to determine whether they were normally distributed or not. Statistical comparisons were made using chi-square tests for categorical data. Student's t-test for two independent samples was used for comparison of continuous numerical data. Variables found to be significant $(p<0.05)$ in univariate analysis were tested in multivariate analysis, which was performed using a stepwise logistic regression model. Survival analyses were performed using the Kaplan-Meier test with log rank. Values of $p<0.05$ were considered statistically significant.

\section{Results}

\section{Patient Characteristics}

A total of 87 patients were included in this study. The median age was 48 (range: 18-70) years at the time of diagnosis. 
The baseline clinical and demographic characteristics of the patients are listed in Table 1. For 66 of 87 patients (75.9\%), the first mobilization trial was successful. Adequate $\left(\geq 2 \times 10^{6} / \mathrm{kg}\right)$ CD34+ cells were collected in the first apheresis for
66 patients $(9.5 \pm 8.1)$. For 21 of $87(24.1 \%)$, the first mobilization trial was unsuccessful. Therefore, a second mobilization trial was conducted for these patients with plerixafor (5.5 \pm 3.3$)$. The number of CD34+ cells was significantly higher in patients who

Table 1. Baseline clinical and demographic characteristics of patients.

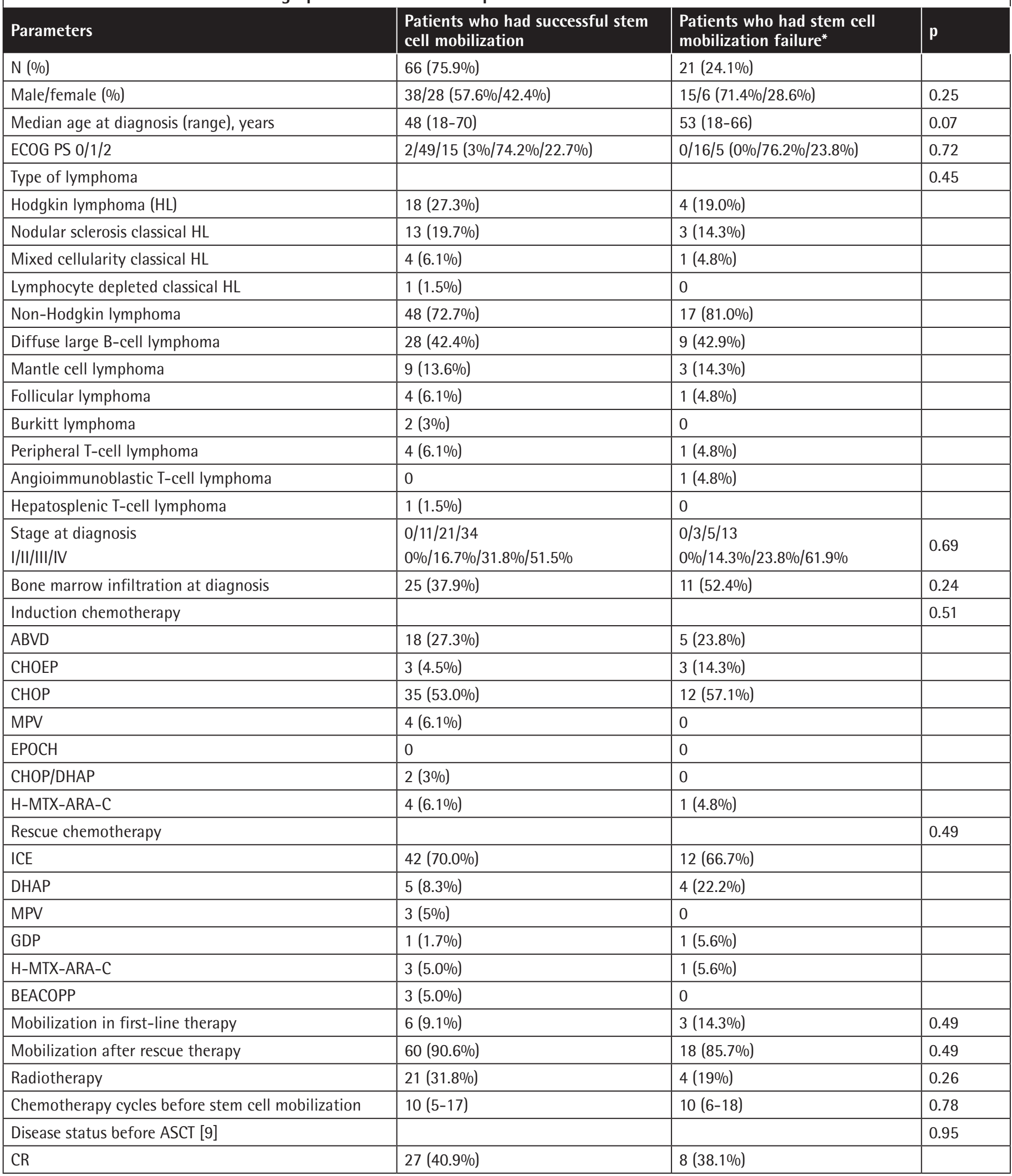




\begin{tabular}{|c|c|c|c|}
\hline Parameters & $\begin{array}{l}\text { Patients who had successful stem } \\
\text { cell mobilization }\end{array}$ & $\begin{array}{l}\text { Patients who had stem cell } \\
\text { mobilization failure* }\end{array}$ & $\mathbf{p}$ \\
\hline Stable disease & $5(7.6 \%)$ & $1(4.8 \%)$ & \\
\hline Progressive disease & $6(9.1 \%)$ & $2(9.5 \%)$ & \\
\hline Mobilization protocol & & & 0.20 \\
\hline Filgrastim & $43(65.2 \%)$ & $18(85.7 \%)$ & \\
\hline Lenograstim & $2(3 \%)$ & $1(4.8 \%)$ & \\
\hline Filgrastim + ICE & $13(19.7 \%)$ & $2(9.5 \%)$ & \\
\hline
\end{tabular}

were successful in the first mobilization $(p=0.002)$. There were no differences in hematocrit at the time point of apheresis.

Between the two groups, there was no statistically significant gender $(p=0.25)$ or age $(p=0.07)$ difference. There was no significant difference between the ECOG PS of the patients $(p=0.72)$. No significant difference was found between the groups in terms of lymphoma types $(p=0.45)$. Number of chemotherapy cycles before stem cell mobilization was not statistically significantly different between patients who had mobilization failure and patients who had successful stem cell mobilization $(p=0.78)$. The stages of both groups were similar at the time of diagnosis $(p=0.69)$. There was no significant difference between bone marrow infiltration at diagnosis $(p=0.24)$. There was no significant difference between the groups in terms of induction chemotherapy protocols $(p=0.51)$. Platelet count before mobilization was higher in patients who had successful stem cell mobilization than in patients who had stem cell mobilization failure $(p=0.041)$. After relapse, no significant difference was found between rescue chemotherapies given before mobilization $(p=0.49)$. Disease status before ASCT was complete response (CR) in $27(40.9 \%)$ patients, partial response $(\mathrm{PR})$ in $28(42.4 \%)$ patients, stable disease in $5(7.6 \%)$ patients, and progressive disease in $6(9.1 \%)$ patients in the successful mobilization group. Disease status before ASCT was CR in $8(38.1 \%)$ patients, PR in $10(47.6 \%)$ patients, stable disease in $1(4.8 \%)$ patient, and progressive disease in $2(9.5 \%)$ patients in the stem cell mobilization failure group for the first trial $(p=0.95)$. The use of filgrastim or lenograstim as G-CSF did not affect mobilization success. There was no significant difference between the two groups in terms of filgrastim or lenograstim mobilization $(p=0.20)$. However, when the patients who received only G-CSF or a chemotherapy-based mobilization protocol were evaluated, 19 (29.7\%) of the patients who were mobilized with only G-CSF had mobilization failure, while only 2 (8.7\%) patients who received a chemotherapy-based mobilization protocol had mobilization failure $(p=0.04)$. This shows the superiority of chemotherapy-based mobilization.

\section{Post-transplant Outcomes}

All of the patients finally underwent ASCT. Remarkably, disease status after ASCT (on day +100) was CR in $38(61.3 \%)$ patients, PR in $1(1.6 \%)$ patients, stable disease in $20(32.3 \%)$ patients, and progressive disease in $3(4.8 \%)$ patients in the successful mobilization group. Disease status after ASCT (on day +100) was CR in $13(65 \%)$ patients, PR in $5(5 \%)$ patients, stable disease in $4(20 \%)$ patients, and progressive disease in $2(10 \%)$ patients in the stem cell mobilization failure group for the first trial, as shown in Table 2. The relapse rate was significantly higher in patients who had stem cell mobilization failure than in those with successful stem cell mobilization $(47.6 \%$ vs. $21.2 \%, p=0.01)$. Moreover, the mortality rate was significantly higher among patients who had stem cell mobilization failure than those with successful stem cell mobilization ( $38.1 \%$ vs. $16.7 \%, p=0.01$ ).

\section{Overall Survival}

The overall survival (OS) rate for patients who had successful stem cell mobilization was $151.6 \pm 9.3$ months versus $71.4 \pm 7.8$ months for patients with stem cell mobilization failure for the first trial; this was a statistically significant difference, as shown in Figure $1(p=0.02)$. The 3 -year OS rates for patients with successful stem cell mobilization and those with stem cell mobilization failure for the first trial were $85 \%$ and $79 \%$, respectively. The 5 -year OS rates for patients with successful stem cell mobilization and stem cell mobilization failure for the first trial were $81 \%$ and $63 \%$, respectively. OS was better in patients with lymphoma for whom the first mobilization trial was successful.

The disease-free survival (DFS) rate for patients who had successful stem cell mobilization was $111.9 \pm 10.6$ months versus 
$57.6 \pm 6.4$ months for patients who had stem cell mobilization failure for the first trial; this was a statistically significant difference, as shown in Figure $2(\mathrm{p}=0.004)$. The 3 -year DFS rates for patients with successful stem cell mobilization and those with stem cell mobilization failure for the first trial were $82 \%$ and 74\%, respectively. The 5-year DFS rates for patients with successful stem cell mobilization and stem cell mobilization failure for the first trial were $68 \%$ and $44 \%$, respectively.

\section{Discussion}

Stem cell mobilization is still difficult in a significant proportion of patients with lymphoma and the factors predicting poor mobilization are still not fully explained. An obvious reason for these difficulties might be the fact that previous studies have been heterogeneous concerning diagnosis, prior therapy, and mobilization regimen used [7]. The frequency of mobilization failure was $24.1 \%$ in the first mobilization in this study,

\begin{tabular}{|c|c|c|c|}
\hline Parameters & $\begin{array}{l}\text { Patients who had successful stem } \\
\text { cell mobilization }\end{array}$ & $\begin{array}{l}\text { Patients with stem cell } \\
\text { mobilization failure* }\end{array}$ & $\mathbf{p}$ \\
\hline Disease status after ASCT [9] & & & 0.53 \\
\hline $\mathrm{CR}$ & $38(61.3 \%)$ & $13(65.0 \%)$ & \\
\hline PR & $1(1.6 \%)$ & $5(5.0 \%)$ & \\
\hline Stable disease & $20(32.3 \%)$ & $4(20.0 \%)$ & \\
\hline Progressive disease & $3(4.8 \%)$ & $2(10.0 \%)$ & \\
\hline Relapse (\%) & $14(21.2 \%)$ & $10(47.6 \%)$ & 0.01 \\
\hline Mortality (\%) & $11(16.7 \%)$ & $9(42.9 \%)$ & 0.01 \\
\hline
\end{tabular}
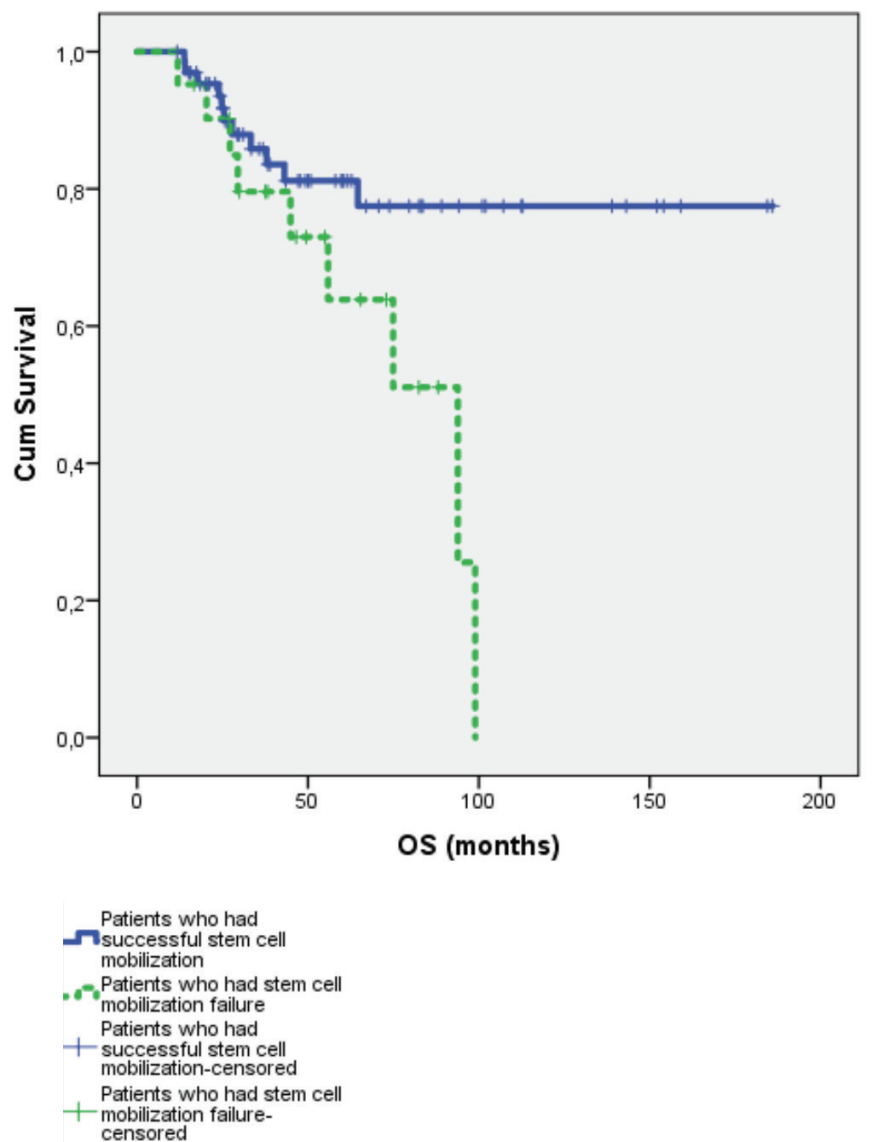

Figure 1. Overall survival (OS) of patients who had successful stem cell mobilization and patients who had stem cell mobilization failure $(p=0.02)$.

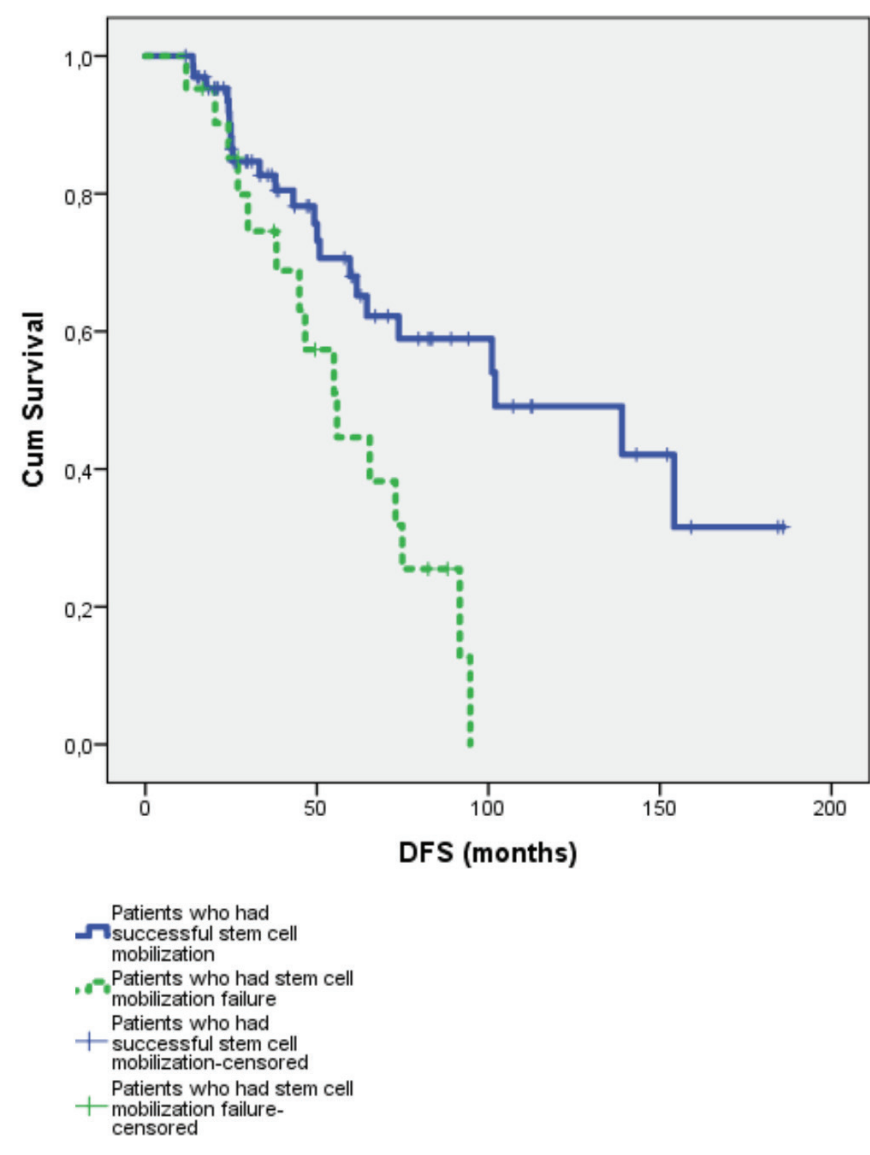

Figure 2. Disease-free survival (DFS) of patients who had successful stem cell mobilization and patients who had stem cell mobilization failure $(p=0.004)$. 
but no factor was detected in analysis that would cause mobilization failure in these lymphoma patients. No statistically significant difference was found between age, sex, stage of diagnosis, ECOG PS, bone marrow infiltration at diagnosis, induction chemotherapy, chemotherapy cycles before stem cell mobilization, disease status before ASCT, receiving radiotherapy before mobilization, lymphoma types, or mobilization regimen in the two groups. On the other hand, OS and DFS were significantly longer in the group with successful mobilization in the first trial. It was observed that survival outcomes were worse in patients who needed plerixafor for mobilization. However, it was thought that the worse survival outcomes might have been due to the poor bone marrow reserve and disease status before ASCT in patients who needed plerixafor for mobilization.

For successful ASCT, one of the most important factors is to mobilize sufficient numbers of CD34+ cells. In this study, the cut-off value of $2 \times 10^{6} \mathrm{CD} 34+$ cells $/ \mathrm{kg}$ body weight was determined as the target for a successful mobilization procedure. It can be thought that the necessity of using plerixafor can be predicted according to the number of peripheral CD34 cells. CD34 cell count on apheresis day was reported to be the best predictor of mobilization failure [10]. Additionally, CD34 cell count was suggestive of preemptive plerixafor use and the authors suggested a low level of CD34+ in peripheral blood on day +13 as a possible criterion for initiating plerixafor administration [11]. In this study, the number of CD34+ cells of the apheresis product was observed to be significantly higher in patients who were successful in the first mobilization.

Recent studies reported that the incidence of mobilization failure in lymphoma was as high as $46 \%[12,13,14]$. Variables already reported to be associated with mobilization failure include age, body weight, diagnosis, type of lymphoma and dose of chemotherapy, extent of cell recovery from chemotherapy, bone marrow involvement of lymphoma cells, prior radiation therapy, and interval from diagnosis to mobilization $[12,13,14,15]$. On the other hand, some hematological parameters such as cytopenia at any stage of mobilization, high mean corpuscular volume, long myelosuppression between salvage chemotherapies, and poor bone marrow microenvironment can predict mobilization failure. Özkurt et al. [16] reported that the CD34+ cell count of the first apheresis product was positively correlated with the white blood cell count, platelet count, peripheral CD34+ cell count, and grade of bone marrow reticulin fibrosis. In this study, chemotherapy-based mobilization was seen to be superior to G-CSF mobilization. Additionally, the platelet count before mobilization was higher in patients who had successful stem cell mobilization than in patients with stem cell mobilization failure. Apart from these two prognostic factors, none of the patient or disease characteristics that we analyzed were associated with mobilization failure. Prognostic factors such as patient characteristics (age, gender, diagnosis, bone marrow involvement, previous number of chemotherapy lines, previous radiotherapy) were also not found to be associated with mobilization failure in previous clinical studies $[12,14]$.

It is not clear whether patients with treatment efficiency may be best mobilized by higher doses of chemotherapy and/or G-CSF. Previously, some studies demonstrated the superiority of chemotherapy plus growth factors over growth factors alone for mobilization $[6,17,18]$. On the other hand, Pusic et al. [17] found similar rates of mobilization failure with chemotherapy plus growth factors and only growth factor. Additionally, André et al. [19] found no significant difference in CD341 cell harvest yields among 131 patients randomized to receive 5 or $10 \mu \mathrm{g} /$ $\mathrm{kg} /$ day of G-CSF following mobilization chemotherapy. In our study, it was observed that mobilization regime did not affect mobilization failure. However, when the patients who received only G-CSF and those who received a chemotherapy-based mobilization protocol were evaluated, chemotherapy-based mobilization was superior.

\section{Conclusion}

In this study, the success rate of the first mobilization trial was found to be higher in patients with high platelet counts before mobilization and in patients who received chemotherapy-based mobilization protocols. This study had a few limitations. First, it was retrospective. Second, all patients did not receive the same induction chemotherapy before mobilization. Third, the diagnoses of the patients were very heterogeneous. For the patients who had mobilization failure in the first trial, plerixafor was used in a later mobilization, and those patients then had an adequate amount of stem cells for ASCT. Parameters predicting mobilization failure would allow for a preemptive, more cost-effective use of such agents during the first mobilization attempt. However, the risk factors for mobilization failure are still not clear.

\section{Ethics}

Ethics Committee Approval: All ethical considerations were strictly followed in accordance with the 1964 Declaration of Helsinki. As standard care/action of the hospitals of the Hacettepe University Medical School Bone Marrow Transplantation Center, Turkey, it has been recognized from the patient records that all of the studied patients had given informed consent at the time of hospitalization and before the administration of relevant diagnostic/therapeutic standards of care.

\section{Informed Consent: Obtained.}

\section{Authorship Contributions}

Surgical and Medical Practices: H.G.; Concept: H.D.; Design: H.D.; Data Collection or Processing: R.Ç.; Analysis or Interpretation: R.Ç.; Literature Search: Y.B.; Writing: R.Ç. 
Conflict of Interest: No conflict of interest was declared by the authors.

Financial Disclosure: The authors declared that this study received no financial support.

\section{References}

1. Sheppard D, Bredeson C, Allan D, Tay J. Systematic review of randomized controlled trials of hematopoietic stem cell mobilization strategies for autologous transplantation for hematologic malignancies. Biol Blood Marrow Transplant 2012;18:1191-1203.

2. Van Gorkom G, Finel $H$, Giebel $S$, Pohlreich $D$, Shimoni A, Ringhoffer M, Sucak G, Schaap N, Dreger P, Sureda A, Schouten HC. Prospective noninterventional study on peripheral blood stem cell mobilization in patients with relapsed lymphomas. J Clin Apher 2017;32:295-301.

3. Siena S, Schiavo R, Pedrazzoli P, Carlo-Stella C. Therapeutic relevance of CD34 cell dose in blood cell transplantation for cancer therapy. J Clin Oncol 2000;18:1360-1377.

4. To LB, Levesque JP, Herbert KE. How I treat patients who mobilize hematopoietic stem cells poorly. Blood 2011;118:4530-4540.

5. Allan DS, Keeney M, Howson-Jan K, Popma J, Weir K, Bhatia M, Sutherland DR, Chin-Yee IH. Number of viable CD34+ cells reinfused predicts engraftment in autologous hematopoietic stem cell transplantation. Bone Marrow Transplant 2002;29:967-972.

6. Mendrone A Jr, Arrais CA, Saboya R, de Alencar Fischer Chamone D, Dulley FL. Factors affecting hematopoietic progenitor cell mobilization: an analysis of 307 patients. Transfus Apher Sci 2008;39:187-192.

7. Kuittinen T, Nousiainen T, Halonen P, Mahlamäki E, Jantunen E. Prediction of mobilisation failure in patients with non-Hodgkin's lymphoma. Bone Marrow Transplant 2004;33:907-912.

8. Oken MM, Creech RH, Tormey DC, Horton J, Davis TE, McFadden ET, Carbone PP. Toxicity and response criteria of the Eastern Cooperative Oncology Group. Am J Clin Oncol1982;5:649-656.

9. Cheson BD, Fisher RI, Barrington SF, Cavalli F, Schwartz LH, Zucca E, Lister TA; Alliance, Australasian Leukaemia and Lymphoma Group; Eastern Cooperative Oncology Group; European Mantle Cell Lymphoma Consortium; Italian Lymphoma Foundation; European Organisation for Research; Treatment of Cancer/Dutch Hemato-Oncology Group; Grupo Español de Médula Ósea; German High-Grade Lymphoma Study Group; German Hodgkin's Study Group; Japanese Lymphorra Study Group; Lymphoma Study Association; NCIC Clinical Trials Group; Nordic Lymphoma Study Group; Southwest Oncology Group; United Kingdom National Cancer Research Institute. Recommendations for initial evaluation, staging, and response assessment of Hodgkin and non-Hodgkin lymphoma: the Lugano classification. J Clin Oncol 2014;32:3059-3068.
10. Ford C, Chan K, Reilly W, Petersen F. An evaluation of predictive factors for CD34+ cell harvest yields from patients mobilized with chemotherapy and growth factors. Transfusion 2003;43:622-625.

11. Milone G, Tripepi G, Martino M, Ancora F, Bartolozzi B, Spadaro A, Nozzoli C, La Fauci A, Amico I, Leotta S, Poidomani M, Irrera G, lacopino P, Saccardi R, Guidi S, Bosi A. Early measurement of CD34+ cells in peripheral blood after cyclophosphamide and granulocyte colony-stimulating factor treatment predicts later CD34+ mobilisation failure and is a possible criterion for guiding "on demand" use of plerixafor. Blood Transfus 2013;11:94-101.

12. Hosing $C$, Saliba RM, Ahlawat $S$, Körbling $M$, Kebriaei $P$, Alousi $A$, De Lima M, Okoroji JG, McMannis J, Qazilbash M, Anderlini P, Giralt S, Champlin RE, Khouri I, Popat U. Poor hematopoietic stem cell mobilizers: a single institution study of incidence and risk factors in patients with recurrent or relapsed lymphoma. Am J Hematol 2009;84:335-337.

13. Rossi G, Skert C, Morello E, Almici C, Arcaini L, Basilico C, Cavalli L, Botto B, Castelli A, Pica G, Ripamonti F, Salvi F, Carella AM, Gaidano G, Levis A, Nosari $A$, Russo D, Vitolo U. PBSC mobilization in lymphoma patients: analysis of risk factors for collection failure and development of a predictive score based on the kinetics of circulating CD34+ cells and WBC after chemotherapy and G-CSF mobilization. Hematol Oncol 2015;33:125-132.

14. 14. Wuchter $P$, Ran $D$, Bruckner $T$, Schmitt $T$, Witzens-Harig $M$, Neben $K$ Goldschmidt $H$, Ho AD. Poor mobilization of hematopoietic stem cellsdefinitions, incidence, risk factors, and impact on outcome of autologous transplantation. Biol Blood Marrow Transplant 2010;16:490-499.

15. Tarella C, Di Nicola M, Caracciolo D, Zallio F, Cuttica A, Omede P, Bondesan $P$, Magni M, Matteucci P, Gallamini A, Pileri A, Gianni AM. High-dose ara-C with autologous peripheral blood progenitor cell support induces a marked progenitor cell mobilization: an indication for patients at risk for low mobilization. Bone Marrow Transplant 2002;30:725-732.

16. Özkurt ZN, Yeğin ZA, Suyanı E, Akı ŞZ, Acar K, Yağcı M, Türköz Sucak G. Factors affecting stem cell mobilization for autologous hematopoietic stem cell transplantation. J Clin Apher 2010;25:280-286.

17. Pusic I, Jiang SY, Landua S, Uy GL, Rettig MP, Cashen AF, Westervelt P, Vij R, Abboud CN, Stockerl-Goldstein KE, Sempek DS, Smith AL, DiPersio JF. Impact of mobilization and remobilization strategies on achieving sufficient stem cell yields for autologous transplantation. Biol Blood Marrow Transplant 2008;14:1045-1056.

18. Fruehauf $S$, Seggewiss R. It's moving day: factors affecting peripheral blood stem mobilization and strategies for improvement. Br J Haematol 2003;122:360-375.

19. André $M$, Baudoux $E$, Bron D, Canon JL, D'Hondt V, Fassotte MF, D'Hondt $L$, Fillet G, Humblet Y, Jerusalem G, Vermeulen P, Symann M, Beguin Y. Phase III randomized study comparing 5 or $10 \mu \mathrm{g}$ per $\mathrm{kg}$ per day of filgrastim for mobilization of peripheral blood progenitor cells with chemotherapy, followed by intensification and autologous transplantation in patients with nonmyeloid malignancies. Transfusion 2003;43:50-57. 